\title{
Mid-Cretaceous ammonite zones, Western Interior, United States
}

\author{
WILLIAM A. COBBAN
}

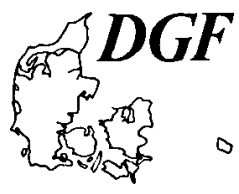

Cobban, W. A.: Mid-Cretaceous ammonite zones, Western Interior, United States. Bull. geol. Soc. Denmark, vol. 33, pp. 71-89, Copenhagen, September, 11th, 1984.

https://doi .org/10.37570/bgsd-1984-33-06

\begin{abstract}
The Western Interior of the United States contains an important sequence of middle Cenomanian-late Turonian ammonites. Ammonites from the northern part of the Western Interior are mostly North Temperate forms, whereas those from the southern part are a mixture of Tethyan and North Temperate forms. The ammonite succession in the southern part can be more finely zoned than that of the northern part, and offers better possibilities for international correlation.

In the zonation, the boundary between the middle and upper Cenomanian is placed at the top of the zone of Plesiacanthoceras aff. $P$. wyomingense. The top of the Cenomanian is drawn at the top of the zone of Neocardioceras juddii as recommended in a 1981 study by C. W. Wright and W. J. Kennedy. However, Mammites nodosoides, which occurs three zones higher, is usually regarded in Europe as basal Turonian, although Wright and Kennedy have now recognized a zone of Watinoceras coloradoense at the base, which lies below the zone of Mammites nodosoides. In the Western Interior, $\boldsymbol{W}$. coloradoense is restricted to the zone of Vascoceras (Greenhornoceras) birchbyi, which is separated from the zone of Neocardioceras juddii by a zone of Pseudaspidoceras flexuosum. Inasmuch as the ammonites in the latter zone are closely related to those in the zone of $V$. birchbyi, a Turonian assignment seems best for the zone of $P$. flexuosum. Collignoniceras woollgari, which is widely distributed in Europe, Asia, and North America, is usually regarded as middle Turonian in a threefold division and late Turonian in a twofold division. I consider the species to mark the base of the middle Turonian. Where to place the top of the middle Turonian, however, is a problem. Inasmuch as the best faunal break is at the top of the zone of Prionocyclus hyatti, that is where the boundary is placed in this report. Inoceramids in the zone of $P$. hyatti are characterized by forms having a radial depression like the middle Turonian Inoceramus hobetsensis of Japan.

The top of the Turonian is designated here at the top of the zone of Prionocyclus quadratus. Fossils of this zone include inoceramids of the fiegei-dresdensis group, which in Europe have been considered either very late Turonian in age or very early Coniacian. Prionocyclus quadratus is the youngest species of a lineage of prionocyclids. This species is succeeded by Forresteria (Solgerites) of Coniacian Age.
\end{abstract}

William A. Cobban, U.S. Geological Survey, Mail Stop 919, Box 25046, Federal Center, Denver, Colorado 80225. March 15th, 1984.

\section{Introduction}

Many zones of ammonites can be recognized in mid-Cretaceous rocks of Albian to Coniacian Age in the Western Interior of the United States. Only those of middle Cenomanian through the Turonian are treated in the present report. The Albian and Coniacian ammonite faunas await further study.

Mid-Cretaceous rocks are widely distributed in the Western Interior (fig. 1). Rocks deposited in the central part of the seaway are chiefly fine grained and mostly shale and carbonates. In general, these rocks thicken westward, where they become less calcareous and intertongue with marine and nonmarine sandy units. Toward the east, the rocks become thinner and overlap rocks as old as Precambrian.
Preservation of the ammonites varies according to the host rock. The best preservation is in concretions of argillaceous limestone or silty sandstone. An occasional concretion may contain hundreds of specimens of a single species. Where concretions are absent, ammonites may occur in great numbers as flattened impressions in darkgray calcareous shale.

Ammonites from the northern part of the Western Interior are mostly North Temperate forms, such as Dunveganoceras and Scaphites, whereas those from the southern part are chiefly North Temperate and South Temperate species. Tethyan forms, such as Vascoceras and Fagesia, are largely confined to the southernmost part of the Western Interior. 


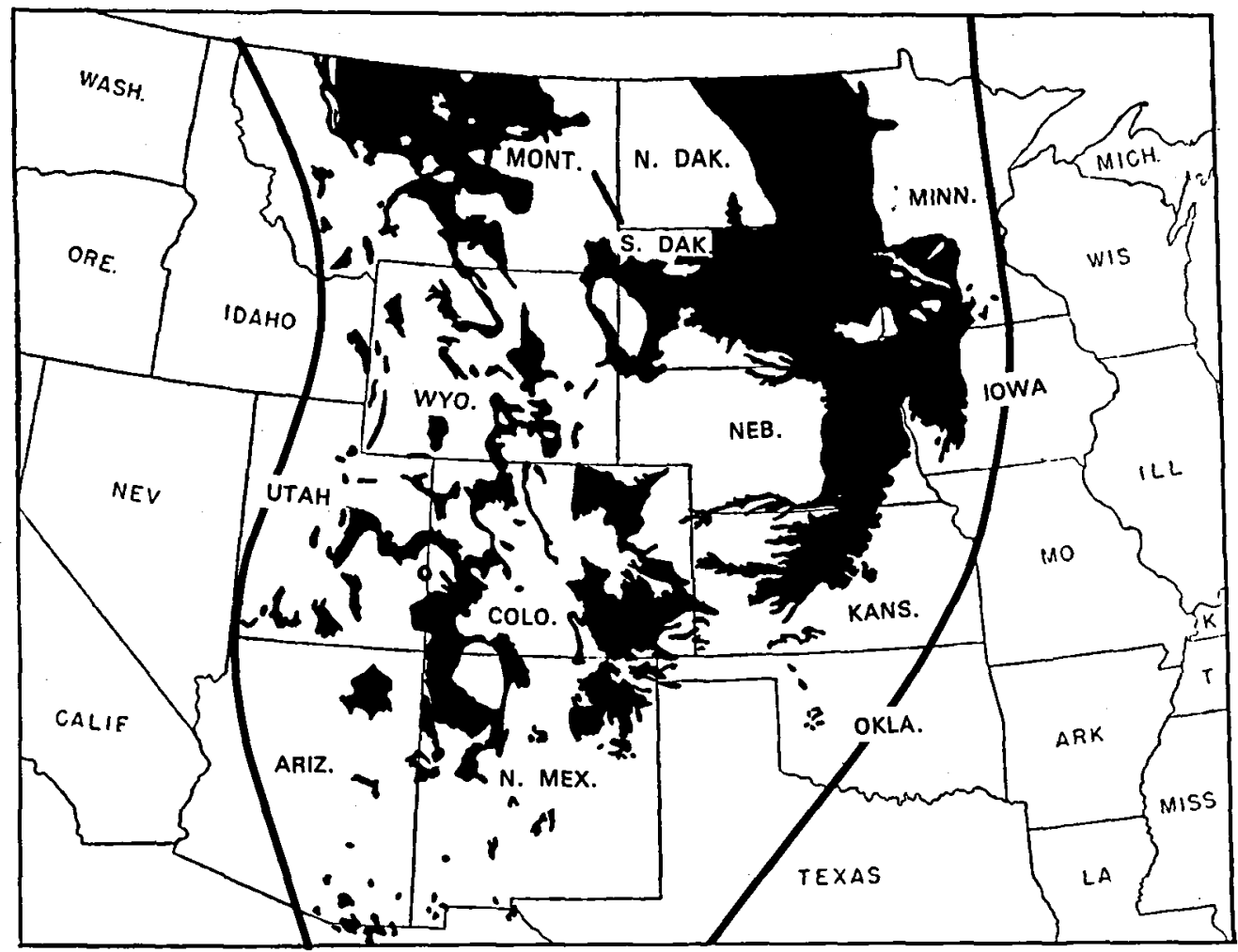

Fig. 1. Map of outcrop areas of Cretaceous sedimentary rocks in the Western Interior of the United States. The heavy black bounding lines show the maximum known extent of the mid-Cretaceous seaway. Modified from Cobban and Reeside (1952, fig. 1).

\section{Historical background}

Rocks chiefly of mid-Cretaceous age in the Western Interior were first named by Meek and Hayden (1861), who recognized a "Lower series" in their Cretaceous sequence that consisted of a "Dakota group, Formation No. 1" at the base overlain by a "Fort Benton group, Formation No. 2" and that in turn by a "Niobrara division, Formation No. 3." Meek and Hayden considered their "Lower Series" to be equivalent to rocks in Europe of Cenomanian and Turonian age. Ammonites were unknown from the Dakota and Niobrara beds at that time. However, from their Formation No. 2, the following ammonites had already been described: Ammonites percarinatus Hall and Meek (1856, p. 396, pl. 4, fig. 2a, b), $A$. vermilionensis Meek and Hayden (1860, p. 177), Scaphites larvaeformis Meek and Hayden (1859, p. 58), and $S$. warreni Meek and Hayden (1860, p. 177). Three additional ammonites (Scaphites ventricosus, $S$. vermiformis, and Ammonites mullananus) were described by Meek and Hayden in 1862 (p. 22, 23) and assigned to the "Fort Benton Group."

By 1878 (White, p. 21, 22, 30), the name "Colorado group" was applied in Colorado to rocks equivalent to Meek and Hayden's Fort Benton and Niobrara divisions. Later Stanton (1893) applied the name "Colorado formation" widely in the Western Interior. He described the fauna and noted that many of the species were related to European forms from the Cenomanian and Turonian as well as to some from the slightly younger "Emscher Mergel" of Germany. Ammonites figured by Stanton are listed below with their present taxonomic assignment. 
Helicoceras pariense White

Helicoceras? corrugatum Stanton

Baculites gracilis Shumard?

Baculites asper Morton?

Buchiceras swallovi (Shumard)

Placenticeras placenta (Dekay)

Prionocyclus wyomingensis Meek

Prionocyclus macombi Meek

Prionotropis woolgari (Mantell)

Prionotropis hyatti Stanton

Prionotropis? loevianus White

Mortoniceras shoshonense Meek

Mortoniceras vermilionense (Meek and Hayden)

Acanthoceras? kanabense Stanton

Scaphites larvaeformis Meek and Hayden

Scaphites vermiformis Meek and Hayden

Scaphites warreni Meek and Hayden

Scaphites ventricosus Meek and Hayden

Scaphites mullananus (Meek and Hayden)
Allocrioceras annulatum (Shumard)

Puebloites corrugatus (Stanton)

Sciponoceras gracile (Shumard)

Baculites asper Morton

Metoicoceras geslinianum (d'Orbigny)

Placenticeras stantoni Hyatt

Prionocyclus wyomingensis Meek

Prionocyclus macombi Meek

Collignoniceras woollgari regulare (Haas)

Prionocyclus hyatti (Stanton)

Acanthoceras amphibolum Morrow?

Protexanites shoshonensis (Meek)

Collignoniceras vermilionense (Meek and Hayden)

Euomphaloceras (Kanabiceras) septemseriatum (Cragin)

Scaphites larvaeformis Meek and Hayden

Clioscaphites vermiformis (Meek and Hayden)

Scaphites warreni Meek and Hayden

Scaphites ventricosus Meek and Hayden

Rhaeboceras mullananum (Meek and Hayden)
The last species probably came from the much younger Bearpaw Shale of Campanian or Maastrichtian Age.

Stanton (1893, p. 51) did not believe the fauna of the "Colorado formation" could be well zoned, and he noted that "Sufficient evidence has been given to show that the invertebrate fauna of the Colorado formation cannot be divided into well defined subfaunas or zones corresponding to those that have been recognized in Europe. It is true that certain types seem to be confined to the upper part and others to the lower part of the formation, but some of the most characteristic species, such as Inoceramus labiatus, range from the bottom to the top. The fauna as a whole may be regarded as the approximate taxonomic equivalent of the Turonian ... The few species that are compared with Cenomanian forms are not important."
A a later date, Stanton (1909, p. 419) believed the Colorado fauna could be zoned and noted "The Colorado fauna as a whole is easily distinguished, although it is developed in several distinct faunal zones and local facies. It is characterized by Inoceramus labiatus and several other specific types of Inoceramus, by certain forms of scaphites, and by the keeled ammonites known as Prionotropis, Prionocyclus, and Mortoniceras." Stanton, however, did not formally define any zones.

Stephenson and Reeside (1938, p. 1636-1638) were the first persons to define some of the midCretaceous faunal zones in the Western Interior. They did not give the zones taxon names, but rather they numbered each zone and listed one to five important species. Their zonation was as follows: 
Zone Typically developed in

$6 \quad$ Upper part of Niobrara Formation

5 Lower part of Niobrara Formation

$4 \quad$ Upper part of Carlile Shale

3 Lower part of Carlile Shale

2 Greenhorn Limestone

1 Graneros Shale
Important species

Inoceramus (Haploscapha) grandis Conrad

Inoceramus deformis Meek, coiled Inoceramus

Prionocyclus wyomingensis Meek, Scaphites warreni Meek and Hayden

Prionotropis woolgari (Mantell), Scaphites larvaeformis Meek and Hayden Inoceramus labiatus Schlotheim, Metoicoceras whitei Hyatt

Gryphaea newberryi Stanton, Exogyra columbella Meek, Exogyra suborbiculata Lamarck, Epengonoceras spp., Acanthoceras spp.
Zone 1 was considered as late Cenomanian and early Turonian. Zones 2-4 were assigned to the Turonian, zone 5 to the early Coniacian, and zone 6 to the late Coniacian and early Santonian. This zonation was presented again by Reeside in 1944 but without the numbers and with a reduction in the number of species listed. Gryphaea newberryi, Exogyra columbella, Epengonoceras, and Acanthoceras were grouped together as Cenomanian. Three zones were recognized for the Turonian, from oldest to youngest, Metoicoceras whitei, Prionotropis woolgari, and Prionocyclus wyomingensis. Inoceramus deformis was assigned to the lower half of the Coniacian, whereas I. (Haploscapha) grandis ranged through the upper half of the'Coniacian and lower half of the Santonian.

Mid-Cretaceous rocks in the Western Interior were first zoned in detail by the author (Cobban, 1951a, fig. 2). The Cenomanian-Coniacian part of this zonation was as follows:

Coniacian Scaphites ventricosus, Inoceramus umbonatus

Scaphites preventricosus, Inoceramus deformis

Turonian Scaphites corvensis, Prionocyclus aff. $P$. reesidei

Scaphites nigricollensis

Scaphites whitfieldi, Prionocyclus wyomingensis

Scaphites ferronensis
Scaphites warreni, Prionocyclus macombi

Scaphites carlilensis, Collignoniceras hyatti

Scaphites larvaeformis, Collignoniceras woollgari

Watinoceras reesidei, Inoceramus labiatus

Sciponoceras gracile, Metoicoceras whitei

Cenomanian Dunveganoceras aff. D. albertense, Metoicoceras n. sp.

Dunveganoceras pondi, Metoicoceras praecox

Acanthoceras? n.sp.

Acanthoceras? amphibolum

Calycoceras spp.

Most of this zonation was adopted by Cobban and Reeside (1952) as a reference sequence for the Western Interior. A zone of Scaphites depressus, considered as early Santonian by Cobban (1951a), was assigned to the late Coniacian by Cobban and Reeside.

As a result of further field work in the northern part of the Western Interior, the mid-Cretaceous zonation was modified a little in several publications (Cobban, 1953a, p. 353; 1953b, p. 47; 1958, p. $117-119 ; 1961$, p. 740$)$. The most important changes were the substitution of Prionocyclus quadratus Cobban for Prionocyclus aff. $P$. reesidei, and the replacement of Acanthoceras? n. sp. by Acanthoceras? wyomingense (Reagan). 
Careful collecting in the Graneros Shale and Greenhorn Limestone in southeastern Colorado made possible other changes in the Western Interior zonation (Cobban and Scott, 1972, tables 2-4). Calycoceras (Conlinoceras) gilberti Cobban and Scott replaced the Calycoceras sp. of earlier zonations, and Plesiacanthoceras wyomingense (Reagan) replaced Acanthoceras? wyomingense. An older zone of Acanthoceras granerosense Cobban and Scott and a younger zone of $A$. muldoonense Cobban and Scott were found to separate the zones of $C$. gilberti and $A$. amphibolum. The former zone of Inoceramus labiatus was replaced by a zone of Watinoceras coloradoense (Henderson) and a younger zone of Mammites nodosides (Schlüter). The zone of Sciponoceras gracile was assigned to the top of the Cenomanian as suggested earlier (Cobban, 1971, p. 18).

An investigation of the middle Turonian ammonite Collignoniceras woollgari in the Western Interior (Cobban and Hook, 1979) revealed that this species consists of an early form, $C$. woollgari woollgari (Mantell) and a later form, $C$. woollgari regulare (Haas). They have been treated both as subzonal indices (Cobban and Hook, 1979, fig. 1; 1983, table 1; Hook and Cobban, 1981, fig. 1) and as zonal indices (Merewether and Cobban, 1981, fig. 1; Merewether, 1983, fig. 7).

Recent field work (Merewether and Cobban, 1981; Merewether, 1983) in the northeastern part of the Western Interior revealed that Ammonites percarinatus Hall and Meek (1856, p. 396, pl. 4, fig. 2a, b) marked a zone between that of Collignoniceras woollgari below and Prionocyclus hyatti above. Hall and Meek's species was later assigned to Subprionocyclus (Cobban, 1983, p. 18). Large collections now available for study suggests the species is better assigned to Prionocyclus.

New field work in the southern part of the Western Interior has made possible further refinements of the Turonian zonation, although most changes are applicable only to that region. Scaphites, which are so important in the northern part of the Western Interior, are much less common in the southern part, and some of the northern species have not been found in the south. Other ammonites, such as Metoicoceras, repre- sented by four zones in the northern part (Cobban, $1953 \mathrm{~b}$, p. 47), are poorly known in the southern part except for $M$. mosbyense Cobban. Some of the keeled ammonites, such as Collignoniceras vermilionense (Meek and Hayden) and Prionocyclus percarinatus (Hall and Meek), which are widely distributed in the north, become scarce in the south. Dunveganoceras, an important genus in the zones of $D$. pondi Haas and Metoicoceras mosbyense in the north, is a rarity in the south. In contrast to these, Tethyan ammonites are important and abundant in rocks at or near the Cenomanian-Turonian boundary in the southernmost part of the Western Interior.

In an attempt to accommodate the geographic differences in the faunas, Cobban and Hook (1979, fig. 1) proposed a different ammonite zonation for the Turonian of the Western Interior. Four zones were recognized for the lower Turonian, from oldest to youngest, Pseudaspidoceras, Nigericeras scotti Cobban, Watinoceras coloradoense-Vascoceras birchbyi, and Mammites nodosoides. The middle Turonian had a zone of Collignoniceras woollgari with the subzones $C$. woollgari woollgari and $C$. woollgari regulare, and a zone of Prionocyclus hyatti-Scaphites carlilensis. Prionocyclus was given a major role in the upper Turonian zonation, where four zones were recognized. The oldest zone was that of $P$. macombi. The next zone was that of $P$. wyomingensis with the subzones of Scaphites warreni and $S$. ferronensis. This was followed by a zone of Prionocyclus novimexicanus with the subzones of Scaphites whitfieldi and $S$. nigricollensis. At the top of the sequence was a zone of Prionocyclus quadratus-Scaphites corvensis. The Turonian zonation was modified a little by Hook and Cobban (1981, fig. 1) as a result of a study (Cobban and Hook, 1980) of the ammonite Family Coilopoceratidae and the recognition of Neocardioceras juddii (Guerne and Barrois) in the Western Interior. The zone of Prionocyclus macombi was divided into a subzone of Coilopoceras colleti Hyatt and a subzone of $C$. inflatum Cobban and Hook. Neocardioceras juddii was used in place of Pseudaspidoceras at the base of the Turonian.

An ammonite zonation for rocks of middle Cenomanian through latest Turonian age was recently proposed for western New Mexico (Cobban and Hook, 1983, table 1). Important changes included the recognition of a zone of Pseudaspi- 


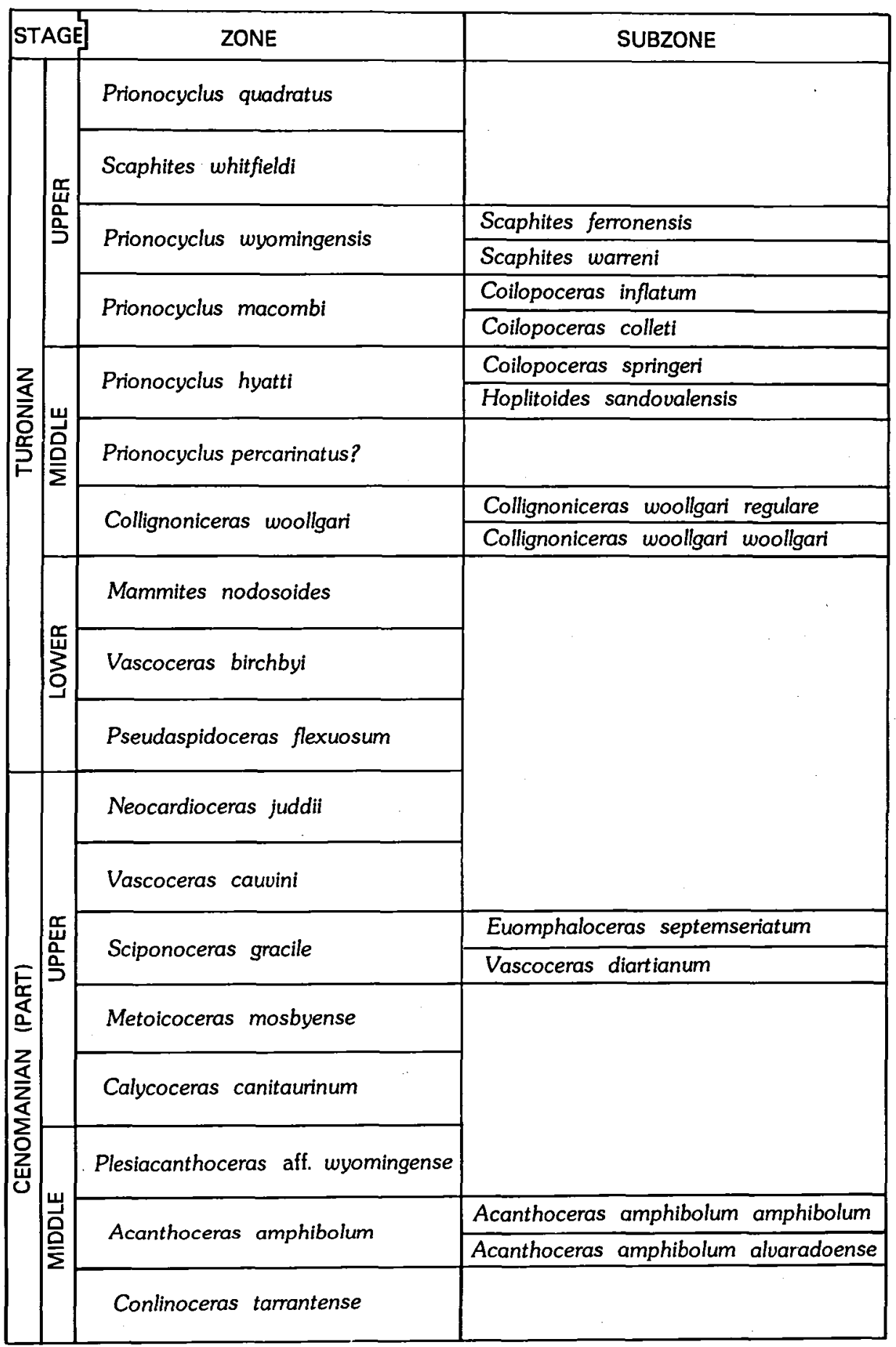

Fig. 2. Middle Cenomanian to upper Turonian ammonite zones and subzones in western New Mexico. 
doceras flexuosum Powell at the base of the Turonian, and the assignment of the zone of Neocardioceras juddii to the top of the Cenomanian. The latter move was made according to the research on $N$. juddii by Wright and Kennedy (1981, table 1, p. 49, 126, 127). In addition, the zone of Prionocyclus hyatti was divided into two subzones, a lower one of Hoplitoides sandovalensis (Cobban and Hook, 1980, p. 8 and illustrations) and an upper one of Coilopoceras springeri Hyatt (1903, p. 96, pl. 12, figs. 1-3).

The middle Cenomanian-upper Turonian ammonite zonation for western New Mexico shown herein (fig. 2) is essentially that of Cobban and Hook (1983, table 1) with a few minor modifications. Plesiacanthoceras wyomingense, which was shown as a subzone in the zone of Acanthoceras amphibolum, has been removed. True $P$. wyomingense has not been found in New Mexico. A closely related form (Cobban, 1977, p. 25, pl. 13, figs. 1,2 ) does occur, and it is indicated by the zone of Plesiacanthoceras aff. wyomingense of figure 2. Two subzones are recognized in the zone of Sciponoceras gracile, a lower one of Vascoceras diartianum, and an upper one of Euomphaloceras septemseriatum. Vascoceras cauvini Chudeau is used in place of Vascoceras gamai, because the former is more abundant and more positively identified. When the fauna at this level is described, some other species will probably be selected as the zonal name. Scaphites whitfieldi is used in place of Prionocyclus novimexicanus, because the former is just as widely distributed but easier to identify.

\section{Ammonite zonation}

\section{Zone of Conlinoceras tarrantense}

Two ammonites from the Lewisville Member of the Woodbine Formation of north-central Texas were named Metacalycoceras? tarrantense and Acanthoceras wintoni by Adkins (1928, p. 241-243, pl. 25, figs. 2, 3; pl. 28, fig. 3; pl. 29, fig. 1). Cobban and Scott (1972, p. 62) concluded that these forms represented one variable species that was not typical of Acanthoceras by having sparse long and short ribbing and a low umbilical wall with reduction in strength of the umbilical tubercles to bullae or even to slightly accentuated ribs. Adkin's forms were assigned to Calycoceras
(Conlinoceras) tarrantense. Because its sparse ribbing and angular whorl section are not typical of Calycoceras, Conlinoceras has been considered an independent genus of middle Cenomanian age (Cobban and Hook, 1983, table 1).

Marine rocks of the age of Conlinoceras tarrantense occur over a large area in the Western Interior. These rocks include the Thatcher Limestone Member of the Graneros Shale of northeast New Mexico and southeast Colorado and the equivalent part of the Graneros Shale north along the Front Range of Colorado and southeast Wyoming. In west-central New Mexico, rocks of this age were deposited in the Seboyeta bay, a west embayment of the middle Cenomanian epeiric seaway, and fossils found in these rocks are referred to as the "Thatcher fauna" (Hook and others, 1980, p. 44). Important fossils in this embayment are the ammonites Conlinoceras tarrantense (time equivalent of $C$. gilberti Cobban and Scott) Turrilites acutus Passy, Borissjakoceras compressum Cobban, and Johnsonites sulcatus Cobban, and the bivalves Inoceramus eulessanus Stephenson, Exogyra columbella Meek, and Plicatula arenaria Meek. The fossils are found mainly in dark-brown-weathering concretions of ferruginous, calcareous sandstone. In northeastern New Mexico and eastern Colorado, the Thatcher fauna occurs in brown-weathering, hard, brittle limestone concretions or in similar beds of concretionary limestone (Cobban and Scott, 1972, p. 10-13 with outcrop photographs).

Farther north in the Western Interior, the Thatcher fauna occurs sparsely in brownweathering, ferruginous, silty beds in the Belle Fourche Shale along the flanks of the Black Hills uplift in western South Dakota, northeastern Wyoming, and southeastern Montana. The few fossils include Inoceramus eulessanus, Exogyra columbella, and Conlinoceras. Farther west, on the southwest flank of the Powder River Basin in north-central Wyoming, thin beds of siltstone and silty, limestone concretions in the Frontier Formation contain Inoceramus eulessanus, Borissjakoceras compressum, and Johnsonites sulcatus, as well as a few fragments of Conlinoceras.

\section{Zone of Acanthoceras amphibolum}

Acanthoceras amphibolum was described originally from the upper part of the Graneros Shale of central Kansas (Morrow, 1935, p. 470, pl. 49, 
figs. 1-4, 6; pl. 51, figs. 3, 4; text fig. 4). This species is a moderate-sized horned acanthoceratid that usually has a low siphonal ridge on the adult body chamber. Acanthoceras alvaradoense Moreman (1942, p. 205, pl. 32, fig. 6 ; text figs. 20,2t), a slightly older species described from the lower part of the Eagle Ford Shale of north-central Texas, has a similar adult body chamber. Because of this similarity, the two forms have been recently considered as one species that consists of an older subspecies, $A$. amphibolum alvaradoense, and a younger form, $A$. amphibolum amphibolum (Cobban and Hook,1983, table 1). The main difference between these two forms is in the early juvenile whorls; those of $A$. amphibolum alvaradoense typically have constrictions and nodate ventrolateral and siphonal tubercles, whereas the early whorls of $A$. amphibolum amphibolum usually lack constrictions and generally have clavate tubercles (for illustrations of these differences, see Cobban, 1977, pl. 6, figs. 1-7; pl. 12, figs. 15, 16 , and Merewether and others, 1979, pl. 1, figs. 1-4).

Acanthoceras amphibolum has been found at many localities in New Mexico, Colorado, Kansas, and Wyoming, as well as along the flanks of the Black Hills uplift in southwestern South Dakota and southeastern Montana. In the Great Plains region, $A$. amphibolum is usually found in gray limestone concretions or in thin calcarenite beds at or near the marker or $\mathrm{X}$ bentonite bed, which lies near the top of the Graneros Shale of Kansas and at the base of the Greenhorn Limestone of Colorado. Fossils usually found with $A$. amphibolum in the Great Plains include abundant Ostrea beloiti Logan, a few inoceramids, and an occasional Turrilities acutus americanus Cobban and Scott, Borissjakoceras reesidei Morrow, or Tarrantoceras sellardsi (Adkins). The inoceramids include $I$. arvanus Stephenson, which is the dominant form in the subzone of $A$. amphibolum alvaradoense, and $I$. rutherfordi Warren, which is the dominant form in the subzone of $A$. amphibolum amphibolum.

In west-central New Mexico, Acanthoceras amphibolum alvaradoense occurs in septarian limestone concretions in the Clay Mesa Tongue of the Mancos Shale. Associated fossils include Inoceramus arvanus, Pycnodonte cf. $P$. kellumi (Jones), Exogyra trigeri Coquand, E. cf. $E$. oxyntas (Coquand), E. levis Stephenson, Ostrea beloiti Logan, Tarrantoceras sellardsi (Adkins), and Cunningtoniceras aff. C. cunningtoni (Sharpe). The Paguate Tongue of the Dakota Sandstone, which overlies the Clay Mesa Tongue, has sandstone concretions that contain Inoceramus rutherfordi, the same pycnodont and exogyras as in the Clay Mesa Tongue, but many more species of bivalves and gastropods (Cobban, 1977, table 1). Ammonites in the Paguate Tongue are Turrilites acutus americanus Cobban and Scott, Desmoceras aff. D. japonicum Yabe, Paracompsoceras landisi Cobban, Tarrantoceras sellardsi, Acanthoceras amphibolum amphibolum, Plesiacanthoceras aff. $P$. wyomingense (Reagan), Cunningtoniceras aff. C. cunningtoni, Pseudocalycoceras n. sp., and Borissjakoceras reesidei Morrow. For illustrations of these ammonites, see Cobban (1977).

On the southwest flank of the Black Hills in eastern Wyoming, Acanthoceras amphibolum alvaradoense occurs in limestone concretions in the upper part of the Belle Fourche Shale. Important associated fossils are Inoceramus arvanus, Acanthoceras aff. $\mathrm{A}$. bellense (Stephenson), $\mathrm{Ca}$ lycoceras leonense (Adkins), and Borissjakoceras orbiculatum Stephenson.

Two zones of ammonites were recognized by Cobban and Scott (1972, table 4) between the zones of $A$. amphibolum and Conlinoceras gilberti in the upper part of the Graneros Shale in the Pueblo area of southeastern Colorado. The younger zone has Acanthoceras muldoonense Cobban and Scott, which is closely related to $A$. amphibolum alvaradoense. The older has $A$. granerosense Cobban and Scott, a rare form known only from the Pueblo area. Owing to their limited geographic distribution and to the probability that they lie in the broad zone of A. amphibolum, the two Pueblo zones are not included herein in the Western Interior zonation.

\section{Zone of Plesiacanthoceras wyomingense}

The holotype of Plesiacanthoceras wyomingense consists of half a phragmocone of a horned acanthoceratid from the Frontier Formation of central Wyoming. The species was briefly described by Reagan (1924, p. 181, pl. 19, figs. 1, 2), who assigned it to Metoicoceras. Later Haas (1963) more thoroughly described the species, assigned it to his new genus Paracanthoceras, and 
illustrated several adults. A year later Haas (1964) noted that his Paracanthoceras was preoccupied and, accordingly, he proposed the genus Plesiacanthoceras. Haas' species is characterized by very early loss of siphonal tubercles and by retention of strong inner and outer ventrolateral tubercles to a large diameter (almost to the base of the adult body chamber) before merging into prominent horns. In addition, ribs weaken and disappear on the outer septate whorl (Merewether and others, 1979, pl. 1, figs. 15, 16).

Plesiacanthoceras wyomingense is abundant in gray limestone concretions and brown ferruginous concretions in the Belle Fourche Shale along the flanks of the Black Hills in southwestern South Dakota, northeastern Wyoming, and southeastern Montana. Farther west in south-central Montana and in the central third of Wyoming, the species is common in siltstone concretions and in ferruginous concretions in the Frontier Formation above the Soap Creek Bentonite Bed. The species has not been found in Colorado. In central Kansas, $P$. wyomingense has been recorded from limestone concretions at or near the base of the Greenhorn Limestone at two localities (Hattin, 1968).

A form closely related to $P$. wyomingense occurs in the Paguate Tongue of the Dakota Sandstone in west-central New Mexico (Cobban, 1977 , p. 25 , pl. 13, figs. 1, 2). Adult body chambers cannot be distinguished from those of $P$. wyomingense from the northern part of the Western Interior, but the septate whorls have a low siphonal ridge. The New Mexican form has been interpreted as $P$. wyomingense high in the zone of Acanthoceras amphibolum (Cobban and Hook, 1983, table 1). Although the New Mexican form and $A$. amphibolum occur in the Paguate Tongue, they have not been found associated. Until more in known about the New Mexican form, it is herein considered as a southern geographic subspecies of $P$. wyomingense.

In the northern part of the Western Interior, fossils occurring with $P$. wyomingense are sparse. Inoceramus prefragilis Stephensen is perhaps the most common. Occasional specimens of Ostrea beloiti Logan and large, smooth exogyras are found locally. Other species of bivalves and gastropods are few. A coarsely ribbed species of Tarrantoceras is present in some colletions as well as a specimen or two of Hamites, Borissjakoceras, or Moremanoceras.

\section{Zone of Dunveganoceras pondi}

The principal guide fossil to this zone was described from the basal part of the Cody Shale of the Bighorn Basin in northwestern Wyoming (Haas, 1949, p. 22, pl. 8, figs. 1-5, 8; pl. 9, figs. 1, 3 , 4; pls. 10-14; text figs. 11-13,16,17). Dunveganoceras pondi is a large, robust ammonite that has early acanthoceratid whorls, later septate whorls without siphonal tubercles, and a body chamber ornamented by strong, equal-sized ribs each of which lacks an umbilical tubercle but rises into a prominent bullate ventrolateral tubercle. On the adult body chamber, ribs either do not cross the venter, or they are weak and depressed on the middle of the venter

Dunveganoceras pondi has been collected at many localities in north-central and south-central Wyoming, where the species occurs mainly in brown-weathering sandstone concretions in the Frontier Formation or in the basal part of the overlying Cody Shale. The species also occurs at many localities in the Orman Lake Limestone Member at the base of the Greenhorn Formation along the flanks of the Black Hills in southwestern South Dakota and northeastern Wyoming. Fragments of $D$. pondi occur in the Lincoln Member at the base of the Greenhorn Limestone in eastern Colorado and central Kansas. The species has not been found south of Colorado.

Ammonites usually found with $D$. pondi include Calycoceras canitaurinum and Metoicoceras praecox - species described by Haas (1949) from the same beds that yielded the types of $D$. pondi. In the western half of New Mexico, a sparsely ribbed form of $C$. canitaurinum has been found at many places in the Whitewater Arroyo Tongue of the Mancos Shale and in the overlying Twowells Tongue of the Dakota Sandstone (Cobban, 1977, p. 23, pl. 21, fig. 17). Ammonites associated with this southern form of $C$. canitaurinum include Neostlingoceras kottlowskii Cobban and Hook (1981) and undescribed species of Tarrantoceras, Moremanoceras, Metoicoceras, and others. Inoceramus prefragilis Stephenson is abundant in beds that contain $D$. pondi as well as in the age equivalent rocks of New Mexico. Other bivalves are fairly scarce but include species of 
Plicatula, Pinna, and Ostrea. Gastropods have been found at only a few localities.

A late form of $D$. pondi has been found in a bed of coarse-grained to conglomeratic sandstone in the Frontier Formation in east-central Wyoming. Other ammonites collected from this bed are Hamites sp., Calycoceras aff. C. canitaurinum, and new species of Moremanoceras, Tarrantoceras, and Metoicoceras.

\section{Zone of Metoicoceras mosbyense}

Metoicoceras mosbyense Cobban (1953b, p. 48, pl. 6, figs. 1-14; pl. 7, figs. 1-3) was described from the Mosby Sandstone Member of the Belle Fourche Shale of cental Montana. Metoicoceras muelleri Cobban (1953b, p. 49, pl. 6, figs. 15, 16; pl. 8, figs. 1-7; pl. 9), which also occurs in the Mosby Member is probably a larger dimorph. Metoicoceras defordi Young (1957, p. 1169, pl. 149, figs. 1-8; text fig. 2a, e, g, i), which was described from eastern Arizona, is probably a geographic variant of $M$. mosbyense that is a little more densely ribbed. All of these forms are characterized by well-ribbed body chambers that lack ventrolateral tubercles.

Metoicoceras mosbyense is widely distributed in the Western Interior from north-central Montana to southwest New Mexico. Aside from many occurrences in concretionary sandstone in the Mosby Member in central Montana, the species occurs in thin lenses of hard siltstone in the Floweree Member of the Marias River Shale in north-central Montana and in the Frontier Formation in the southern part of the State. In Wyoming, $M$. mosbyense has been found in sandstone beds in the Frontier Formation at many localities in the north-central and central parts of the State and in thin beds of calcarenite in the Hartland Shale Member of the Greenhorn Formation along the west side of the Black Hills. Occurrences in Colorado are few and largely confined to calcarenite beds in the Hartland Member along the Front Range and to silty beds in the Benton Shale in the north-central part of the State. In western New Mexico, eastern Arizona, and southern Utah, $M$. mosbyense is known from many localities in sandstone beds at or near the top of the main body of the Dakato Sandstone or from the Twowells Tongue of the Dakota.
Dunveganoceras albertense (Warren) and $D$. conditum Haas are common associates of $M$. mosbyense in Montana and Wyoming. In the Black Hills area, other ammonites are present sparingly such as Moremanoceras scotti (Moreman), Euomphaloceras (Kanabiceras) n. sp., and fragments of Hamites and Metaptychoceras. In eastern Arizona and southwestern New Mexico, $M$. mosbyense is found with Calycoceras obrieni Young, large specimens of a horned Cunningtoniceras and rare specimens of Moremanoceras and Hamites.

Bivalves and gastropods occur abundantly with $M$. mosbyense in some areas. The Mosby Sandstone Member in central Montana locally has masses of coquinoidal calcareous sandstone made up almost entirely of gastropods, chiefly Pseudomelania hendricksoni Henderson (Cobban, 1951a, p. 2185). Inoceramus ginterensis Pergament is a common associate of $M$. mosbyense in sandstone in the Frontier Formation in central Wyoming. In southern Utah, Exogyra olisiponensis Sharpe occurs with $M$. mosbyense, and in eastern Arizone large specimens of Exogyra levis Stephenson are an associate. Along the ArizonaNew Mexico boundary, the Twowells Tongue of the Dakota Sandstone contains representatives of Nemodon, Pinna, Inoceramus, Pteria, Phelopteria, Lopha, Exogyra, Pecten (Camptonectes), Plicatula, Lima, Homomya, Veniella, Callistina, as well as several genera of gastropods.

Bergquist (1944) recorded from Cretaceous rocks in northern Minnesota, a late Cenomanian fauna of 41 species and varieties of bivalves, 12 species of gastropods, 4 species of ammonites, and a species each of an annelid, bryozoan, brachiopod, and scaphopod, as well as fragments of arthropods and teeth and bones of sharks, fish, and reptiles. This fauna is probably in the zone of Metoicoceras mosbyense. The ammonites from northern Minnesota were listed by Bergquist (1944, p. 10) as Metacalycoceras? sp., Acanthoceras sp., Metoicoceras aff. swallovi (Shumard), and Epengonoceras cf. dumblei (Cragin). These have been recently updated (Cobban, 1983). The first two represent Dunveganoceras hagei Warren and Stelck, and the other two are Metoicoceras bergquisti Cobban and $\mathrm{Me}$ tengonoceras dumbli (Cragin). 


\section{Zone of Sciponoceras gracile}

The name bearer for this zone was described as Baculites gracilis Shumard (1860, p. 596) from the Eagle Ford Shale of northern Texas. The straight shell, very small angle of taper, stout ellipical section, well-ribbed venter, and constrictions spaced about 1 to 1.5 diameters characterize the species.

Sciponoceras gracile is widely distributed in Montana, Wyoming, South Dakota, Kansas, Colorado, Utah, Arizona, New Mexico, and Oklahoma. Most occurrences are from limestone beds or limestone concretions in the following stratigraphic units; Cone Member of Marias River Shale (west-central Montana), Greenhorn Formation (southeastern Montana and western South Dakota), basal part of Bridge Creek Member of Greenhorn Limestone (eastern Colorado, southwestern Kansas, northeastern New Mexico, northwestern Oklahoma), Greenhorn Limestone Member of Mancos Shale (northwestern New Mexico), Bridge Creek Limestone Member of Colorado Formation (southwestern New Mexico), basal part of Mancos Shale (northeastern Arizona), and basal part of Tropic Shale (southern Utah). In north-central Wyoming, $S$. gracile has been found in thin beds of sandstone in the Frontier Formation, and in south-central Wyoming, the species occurs in limestone concretions in the Frontier.

Fossils associated with $S$. gracile are sparse and of low diversity in west-central Montana. Inoceramus pictus $\mathrm{J}$. de C. Sowerby and Lucina juvensis Stanton are the usual associates. In north-central Wyoming and along the northeast and north flanks of the Black Hills, a much more diverse fauna occurs including Worthoceras vermiculus (Shumard), W. gibbosum Moreman, Scaphites brittonensis Moreman, Allocrioceras annulatum (Shumard), Euomphaloceras (Kanabiceras) septemseriatum (Cragin), Metoicoceras geslinianum (d'Orbigny), and Placenticeras sp. Among the associated fossils from this area are occasional solitary corals, Inoceramus pictus, and a few examples of Solemya, Pteria, Lucina, Anisomyon, and Cerithiopsis. This diverse fauna persists southward through eastern Colorado, where the additional ammonites Anisoceras plicatile (J. Sowerby), Metaptychoceras reesidei (Cobban and Scott), Puebloities corrugatus (Stanton), Moremanoceras scotti (Moreman),
Calycoceras naviculare (Mantell), and Pseudocalycoceras dentonense (Moreman) appear. Echinoids, which appear with $S$. gracile in the Pueblo area of southeastern Colorado, are also found with it in west-central and south-central New Mexico. Most of this varied ammonite fauna occurs also in Kansas, New Mexico, Arizona, and Utah. In southern Utah, the ammonites are found with a large fauna of bivalves and gastropods, many of which were described by Stanton (1893). Among the bivalves is Pycnodonte newberryi (Stanton), which is present abundantly over much of the Four Corner states (Hook and Cobban, 1977).

In southwestern New Mexico, gray calcareous concretions in the Bridge Creek Member of the Colorado Formation contain Sumitomoceras bentonianum (Cragin), S. cf. S. conlini Wright and Kennedy, and $S$. sp. in addition to Sciponoceras gracile, Worthoceras vermiculus, W. gibbosum, Allocrioceras sp., Euomphaloceras (Kanabiceras) septemseriatum, Pseudocalycoceras dentonense, Metoicoceras geslinianum, and several species of bivalves and gastropods. An extensive coral thicket is also present at one locality.

The zone of Sciponoceras gracile can be divided into two subzones at some localities in the Black Hills area and in southwestern New Mexico. The older subzone is marked by Vascoceras diartianum (d'Orbigny), an early form of Pseudocalycoceras dentonense, and a keeled Euomphaloceras (Kanabiceras). The younger subzone contains the typical $E$. $(K$.) septemseriatum fauna listed above.

\section{Zone of Vascoceras cauvini}

In southwestern New Mexico, an ammonite fauna is present in limestone concretions in the Bridge Creek Member of the Colorado Formation just above beds of limestone and concretions that contain the Sciponoceras gracile fauna. The dominant ammonite is a small, slender vascoceratid that can be assigned to Vascoceras cauvini Chudeau (1909, p. 68, pls. 1, 2; 3, figs. $1 \mathrm{~b}, 2 \mathrm{~b}, 4 \mathrm{a}, \mathrm{b})$. Other vascoceratids include small, stout immature specimens indistinguishable from the inner whorls of Vascoceras gamai Choffat (1898, p. 54 , pl. 7, figs. 1-4; pl. 8, fig. 1; pl. 10, fig. 2; pl. 21, figs 1-5). Adults have not been found in New Mexico. The fauna also includes a larger Kamerunoceras-like genus, Placenticeras, 
Sciponoceras, and one or more small undescribed genera. The few inoceramids found suggest the pictus group.

\section{Zone of Neocardioceras juddii}

The small, ornate ammonite Neocardioceras juddii was first described from the Paris Basin in France (Barrois and de Guerne, 1878, p. 46, pl. 1, figs. 1, 2), where it was assigned to $A m$ monites. The species characterizes the Neocardioceras Pebble Bed at the base of the Middle Chalk of England (Kennedy, 1970, p. 659). Wright and Kennedy (1981, p. 49, pl. 9, figs. 1-20; text figs. $17,19 \mathrm{H}-\mathrm{J}, \mathrm{L})$ have thoroughly described the species and noted that it formed a distinct zone above the zone of Metoicoceras geslinianum (d'Orbigny), which has Sciponoceras gracile. Wright and Kennedy also recorded $N$. juddii from England, Belgium, France, Germany, Czechoslovakia, and the United States.

In the United States, $N$. juddii has been found above beds containing the $S$. gracile fauna in Texas, New Mexico, Arizona, Utah, Wyoming, and Montana, The Texas specimens are flattened impressions in the Eagle Ford Shale (Moreman, 1927, p. 96, pl. 14, fig. 2). In southwestern New Mexico, the species is abundant in limestone concretions or as internal molds in the Colorado Formation (Hook and Cobban, 1981, pl. 1, figs. 5-8) just above beds containing Vascoceras cauvini. In northeastern Arizona, the species occurs in limestone concretions in the lower part of the Mancos Shale, and farther south in east-central Arizona, a few specimens occur in sandy limestone concretions in an unnamed Cretaceous sandstone. Utah localities are in the southern part of the State, where the species is found as crushed impressions in calcareous shale in the lower part of the Tropic Shale. Wyoming localities are composed of sandy beds in the Frontier Formation. In Montana, $N$. juddii has been found in limestone concretions at the base of a thick bed of bentonite (bed $\mathrm{M}$ of Knechtel and Patterson, 1956, p. 21) considered as the base of the Greenhorn Member of the Cody shale.

In most areas, very few other mollusks are found with $N$. juddii. An exception is in southwestern New Mexico, where $N$. juddii is associated with inoceramids of the pictus group, Pseudaspidoceras pseudonodosoides (Choffat), Vascoceras hartti Hyatt, a Kamerunoceras-like genus, Thomasites, Anisoceras, Hamites, and rare Sciponoceras and Worthoceras.

\section{Zone of Pseudaspidoceras flexuosum}

Pseudaspidoceras flexuosum Powell (1963, p. 318 , pl. 32, figs. 1,9 , 10; text fig. 2a-c, f, g) was described from a thin bed of limestone in the Ojinaga Formation in Chihuahua, Mexico. This large species has a body chamber characterized by weak, flexuous ribbing and widely spaced umbilical tubercles and ventrolateral spines. The species occurs with ammonites identified by Powell as Mammites nodosoides (Schlotheim), Acanthoceras calvertense Powell, Acanthoceras sp., Fagesia haarmanni Böse, Pachyvascoceras compressum (Barber), P. globosum Reyment, Vascoceras sp., Allocrioceras sp., Quitmaniceras reaseri Powell, and $Q$. brandi Powell.

Wright and Kennedy (1981, p. 83) assigned $P$. flexuosum to Ampakabites after drawing attention to problems concerning the inner whorls of Pseudaspidoceras footeanum (Stoliczka), the type species of Pseudaspidoceras Pervinquière. Inasmuch as the adult whorls of $P$. footeanum are almost identical to those of $P$. flexuosum, it seems best to retain Powell's generic assignment until more is known regarding the inner whorls of Stoliczka's species.

Poorly preserved fragments of $P$. flexuosum have been found in southwestern New Mexico in very fine grained sandstone beds just above limestone concretions that contain the Neocardioceras juddii fauna. Quitmaniceras reaseri Powell and Fagesia haarmanni Böse were found with them. Other fossils are scarce but include Pycnodonte newberryi (Stanton). Poorly preserved Pseudaspidoceras flexuosum have also been found farther north along the Arizona-New Mexico boundary area midway between the Four Corners and the Mexican border. The only other fossils are numerous specimens of $P$. newberryi.

\section{Zone of Vascoceras birchbyi}

This zone is marked by the large, robust ammonite Vacoceras (Greenhornoceras) birchbyi Cobban and Scott (1972, p. 85, pl. 22; pl. 23, figs. $1-13$; pl. 24 , figs. $1-12$; pl. 25 ; pl. 26 , figs. $5-8$, 11,12 ; pl. 27 , figs. $1-6$; text figs. $43-47$ ). This species has constrictions on the early whorls and well ribbed later whorls that have umbilical tubercles and incipient ventrolateral tubercles. 
Large adult body chambers have a rectangular whorl section and may or may not have ornamentation.

At its type locality near Pueblo, Colorado, $V$. birchbyi occurs in a single bed of limestone in the middle of the Bridge Creek Member of the Greenhorn Limestone. Aside from Mytiloides aff. $M$. duplicostatus (Anderson), most of the fossils in this bed are ammonites including Puebloites spiralis Cobban and Scott, Watinoceras coloradoense (Henderson), W. aff. W. reesidei Warren, Neoptychites cephalotus (Courtiller), Neoptychites sp., Fagesia sp., and Ampakabites collignoni Cobban and Scott. Vascoceras birchbyi occurs in this bed of limestone all along the Front Range in Colorado, eastward into Kansas, and southward into northeastern New Mexico. Vascoceras birchbyi has not been found north of Colorado. Fragments of ammonites that may be $V$. birchbyi are present in thin beds of very fine grained sandstone in the lower part of the Colorado Formation in southwestern New Mexico. These fragments are several meters above beds that contain the Pseudaspidoceras flexuosum fauna.

\section{Zone of Mammites nodosoides}

The zone of Mammites nodosoides (Schlüter) has been recorded from much of the northern hemisphere. The index fossil has recently been treated in much detail and well illustrated by Wright and Kennedy (1981, p. 75, pl. 17, fig. 3; pl. 19, fig. 3; pl. 20 , fig. 4 ; pl. 22, fig. 4 ; pl. 23, figs. 1-3; pl. 24 , figs. 2, 3; text figs. 19B, 23, 24).

Mammites nodosoides has been found in limestone beds in the upper part of the Bridge Creek Member of the Greenhorn Limestone along the Front Range in Colorado (Cobban and Scott, 1972) and southward into northeastern New Mexico (Pillmore and Eicher, 1976). Good examples of the species have also been found in limestone concretions in the upper part of the Rio Salado Tongue of the Mancos Shale in west-central New Mexico (Cobban and Hook, 1983). In both areas, the species is associated with Mytiloides mytiloides (Mantell). Ammonites found in the zone of $M$. nodosoides along the Front Range in Colorado are Puebloites greenhornensis Cobban and Scott, Baculites yokoyamai Tokunaga and Shimizu, Tragodesmoceras bassi Morrow, T. sp., Kamerunoceras puebloense
(Cobban and Scott), Morrowites wingi (Morrow), $M$. depressus (Powell), Vascoceras sp., and Choffaticeras pavillieri (Pervinquière). Limestone concretions in the Rio Salado Tongue in New Mexico contain some of these species as well as some others. The ammonites are Baculites yokoyamai, Tragodesmoceras socorroense Cobban and Hook, Placenticeras cumminsi Cragin, Morrowites wingi, $M$. depressus, $M$. subdepressus Cobban and Hook, $M$. cf. $M$. dixeyi (Reyment), Kamerunoceras turoniense (d'Orbigny), Neoptychites cephalotus (Courtiller), Fagesia superstes (Kossmat), and Cibolaites molenaari Cobban and Hook. Associated with these are numerous species of bivalves and gastropods (Cobban and Hook, 1983, p. 5).

\section{Zone of Collignoniceras woollgari}

Collignoniceras woollgari (Mantell), which is widely distributed over the northern hemisphere, was first described from the Middle Chalk of England (Mantell, 1822, p. 197, pl. 21, fig. 16; pl. 22, fig. 7). The holotype and other examples have been fully described and illustrated by Kennedy, Wright, and Hancock (1980). In the Western Interior, C. woollgari occurs in two forms, an older one ( $C$. woollgari woollgari) typical of the English holotype, and a younger one $(C$. woollgari regulare) that has more uniform ornament. Both forms were treated by Cobban and Hook (1979).

Collignoniceras woollgari woollgari (Mantell) has been found in limestone beds in the uppermost part of the Bridge Creek Member of the Greenhorn Limestone in the Great Plains area from southeastern Colorado and Kansas northward to the Black Hills. Mytiloides mytiloides (Mantell) and M. subhercynicus (Seitz) are usually found with this ammonite in this area. In east-central Wyoming, C. woollgari woollgari was collected from sandstone in the Frontier Formation. The few associated fossils are Inoceramus cuvieri J. Sowerby, Baculites yokoyamai Tokunaga and Shimizu, Tragodesmoceras sp., and Actinocamax sp. Collignoniceras woollgari woollgari is also found in sandstone in western Colorado and east-central Utah. Brown-weathering sandstone concretions in a sandstone unit in the lower part of the Mancos Shale in western Colorado contain species of Pinna, Exogyra, Pycnodonte?, Camptonectes, Pleuriocardia (Dochmocardia), Cymbophora, Legumen, Later- 
nula, a corbulid, and Paleopsephaea, in addition to the ammonite subspecies. In south-central and west-central New Mexico, C. woollgari woollgari occurs in sandstone concretions in the Atarque Sandstone Member of the Tres Hermanos Formation together with a large and varied assemblage of bivalves and gastropods (Cobban and Hook, 1979, p. 11). Other ammonites in these Atarque concretions are Baculites yokoyamai Tokunaga and Shimizu, Tragodesmoceras sp., Placenticeras cumminsi Cragin, Spathites rioensis Powell, and Hoplitoides cf. H. wohltmanni (von Koenen). Limestone concretions in the upper part of the underlying Rio Salado Tongue of the Mancos Shale contain the same ammonites with the addition of Tragodesmoceras socorroense Cobban and Hook, Watinoceras cobbani Collignon, Morrowites depressus (Powell), M. subdepressus Cobban and Hook, Neoptychites? sp., and Hoplitoides wohltmanni (von Koenen). Inoceramids from this part of the Rio Salado Tongue and from the overlying Atarque Member are Inoceramus cuvieri, Mytiloides mytiloides, and $M$. subhercynicus.

Collignoniceras woollgari regulare (Haas) is more widely distributed in the Western Interior than $C$. woollgari woollgari. Specimens have been collected from near the Canadian border in northern Montana southward into northwestern New Mexico. The best collections are from limestone concretions in the Pool Creek Member of the Carlile Shale along the flanks of the Black Hills in western South Dakota and northeastern Wyoming. These concretions also have Scaphites larvaeformis Meek and Hayden and Tragodesmoceras carlilense Cobban as well as rare specimens of hamitids and Binneyites carlilensis Cobban. Other fossils in these concretions are Inoceramus fragilis Hall and Meek and the gastropods Pseudomelania hendricksoni Henderson and Anisomyon apicalis Sidwell.

Far to the east, in the northeastern corner of South Dakota, C. woollgari regulare occurs in hard, concretionary limestone that rests on Precambrian granite (Merewether, 1983, fig. 8). Other ammonites in this limestone are Baculites cf. B. yokoyamai Tokunaga and Shimizu, Scaphites delicatulus sloani Cobban, Otoscaphites seabeensis Cobban and Gryc, Tragodesmoceras carlilense Cobban, Placenticeras stantoni Hyatt, $P$. cumminsi Cragin, and Binneyites carlilensis Cobban. The belemnite Actinocamax manitobensis
(Whiteaves) is abundant. Inoceramids include Inoceramus apicalis Woods and 1 . fragilis Hall and Meek.

Collignoniceras woollgari regulare is found as flattened impressions in the calcareous Fairport Member of the Carlile Shale in southeastern Colorado and central Kansas. Hattin (1962, p. 54) listed a variety of bryozoans, annelids, inoceramids, oysters, and fish teeth as well as $S c a$ phites patulus Cobban and Actinocamax manitobensis (Whiteaves) from the Kansas Fairport.

In west-central New Mexico, $C$. woollgari regulare occurs in thin beds of siltstone in the Mancos Shale. Other fossils are scarce, but include rare specimens of Spathites chispaensis Kummel and Decker. Farther west, in northeastern Arizona, C. woollgari regulare has been found in a nearshore sandstone unit in the Toreva Formation (J. I. Kirkland, oral commun., 1982). Here the species occurs with a large assemblage of bivalves and gastropods.

Many collections from the Western Interior have small specimens of $C$. woollgari. At diameters less than 30 or $40 \mathrm{~mm}$, the two subspecies of this species cannot be separated. Most of the collections form the Mancos Shale of northwestern New Mexico and southwestern Colorado, from the Tropic Shale of southern Utah, from the Allen Valley Shale of south-central Utah, and from the Frontier Formation of northern Utah and western Wyoming consist of these small specimens.

\section{Zone of Prionocyclus percarinatus}

Hall and Meek (1856, p. 396, pl. 4, fig. 2a, b) described a small keeled ammonite, Ammonites percarinatus, that was found as flattened specimens in shale and siltstone in rocks now assigned to the Carlile Shale of northeastern Nebraska. The species has recently been assigned to $S u b$ prionocyclus because the serrations on the keel match the ribs, and on most specimens, the outer ventrolateral tubercle is dominant over the inner one (Cobban, 1983, p. 18). However, the resemblance of the Nebraska specimens and some of the fine-ribbed forms of Prionocyclus hyatti (Stanton) suggests that $A$. percarinatus might be better assigned to Prionocyclus.

In the type areas of $P$. percarinatus in northeastern Nebraska and southeastern South Dakota, few fossils occur in the Carlile Shale. The 
only ammonites found with $P$. percarinatus are Scaphites patulus Cobban, Pteroscaphites sp., Collignoniceras vermilionense (Meek and Hayden), and Placenticeras sp. Other fossils are Inoceramus cuvieri J. Sowerby, I. fragilis Hall and Meek, $I$. cf. $I$. corpulentus McLearn, and Anomia subquadrata Stanton. Along the southwest side of the Black Hills in southwestern South Dakota, $P$. percarinatus is locally abundant in limestone concretions in the Pool Creek Member of the Carlile Shale. These concretions also contain Inoceramus fragilis, Scaphites patulus, and Collignoniceras vermilionense as well as the gastropod Anisomyon apicalis Sidwell and numerous fish scales.

In other parts of the Western Interior, $P$. percarinatus is not positively known. Poorly preserved ammonites in thin beds of siltstone and very fine grained sandstone in the Mancos Shale of westcentral New Mexico may represent this species (Hook and others, 1983, fig. 2).

\section{Zone of Prionocyclus hyatti.}

The name bearer was described as Prionotropis hyatti by Stanton (1893, p. 176, pl. 42, figs. 5-8). This keeled ammonite is moderately evolute and well ornamented by ribs of irregular size that bear inner and outer ventrolateral tubercles. The keel is serrated, and on the inner whorls, the serrations tend to match the ribs in number and in strength. On the adult body chamber, the serrations on the keel are a little more numerous than the ribs.

The types are from the Codell Sandstone Member of the Carlile Shale of south-central Colorado, where they occurred in sandstone concretions with a large and varied assemblage of bivalves and gastropods (Stanton, 1893, p. 29). At the time Stanton described the fauna, the sandstone was unnamed, and Stanton referred to it as the Pugnellus sandstone for the great abundance of the gastropod Pugnellus fusiformis Stanton. In addition to the Pugnellus, Stanton figured 23 species of bivalves and 16 species of gastropods from this sandstone. The only ammonite recorded, other than $P$. hyatti, was Placenticeras sp.

Prionocyclus hyatti is widely distributed in the Western Interior from the Canadian border south into south-central New Mexico. In the northern part of the region, the species is found in dusky- red ironstone concretions or in siltstone lenses in the Ferdig Member of the Marias River Shale in northwestern Montana and in similar rocks in the Carlile Shale of central Montana and Carlile Member of the Cody Shale of south-central Montana. Associated fossils are scarce, usually consisting of poorly preserved inoceramids or an occasional Scaphites carlilensis Morrow. The species is more abundant in ironstone concretions in the upper part of the Pool Creek Member of the Carlile Shale around the north end of the Black Hills in western South Dakota, northeastern Wyoming, and the southeast corner of Montana. On the northeast side of the Black Hills, Scaphites carlilensis, $S$. arcadiensis Moreman, Placenticeras sp., and Binneyites sp. have been found with $P$. hyatti. Other fossils include Inoceramus flaccidus White, small oysters, Exogyra sp., and the arthropods Homarus brittonestris Stenzel, Linuparus grimmeri Stenzel, and $L$. watkinsi Stenzel as well as berycoid fish.

Ironstone and limestone concretions in the Blue Hill Member of the Carlile Shale of northcentral Kansas contain many well-preserved specimens of $P$. hyatti including adults nearly 300 $\mathrm{mm}$ in diameter. Scaphites carlilensis, $S$. arcadiensis, and Inoceramus flaccidus are usually found with it. Crick (1978) recently described the new species Scaphites hattini, S. mitchellensis, S. inflexus and $S$. kansiensis from these beds. The holotype of Binneyites aplatus (Morrow) also came from the Blue Hill Member. Hattin (1962, p. 79) listed 11 species of bivalves and gastropods, a Placenticeras, two arthropods, and several shark teeth from the member. One of the arthropods listed as Raninella? sp. was later described as Raninella carlilensis Feldmann and Maxey (1980).

Siltstone concretions and beds of olive-gray very fine grained sandstone in the Frontier Formation in central and south-central Wyoming contain P. hyatti at several localities. Other molluscan species are scarse, but include an occasional specimen of Placenticeras cumminsi Cragin and, at one locality, Pteroscaphites n. sp. Rhynchostreon aff. $R$. suborbiculata (Lamarck) is present locally, and Inoceramus howelli White and 1 . flaccidus White are abundant in places.

In western Colorado and northeastern Utah, $P$. hyatti has been collected from thin beds of siltstone or very fine grained sandstone in the Man- 
cos Shale or in the Frontier Sandstone Member of the Mancos. Only fragments of inoceramids and small oysters were found with it. In eastcentral Utah, $P$. hyatti occurs in brown-weathering sandstone concretions in a sandstone bed in the Mancos Shale. Other fossils are mainly wellpreserved specimens of Inoceramus flaccidus. Farther south in south-central and southern Utah, $P$. hyatti is found in siltstone and ironstone concretions in the Tununk Member of the Mancos Shale and in sandy beds high in the Tropic Shale. Associated bivalves are scarce; most are Inoceramus howelli.

Prionocyclus hyatti is known from many localities in north-central and west-central New Mexico and from one locality in the south-central part. Two subzones can be recognized, a lower one characterized by Hoplitoides sandovalensis Cobban and Hook and an upper one by Coilopoceras springeri Hyatt. Ammonites found in the older subzone include Herrickiceras costatum (Herrick and Johnson), Spathites puercoensis (Herrick and Johnson), and Romaniceras kallesi (Zázvorka). A specimen of the latter from New Mexico has been illustrated by Kennedy, Wright, and Hancock (1980, pl. 45, fig. 2). The younger subzone has an occasional fragment of $R o$ maniceras. Both subzones have Inoceramus howelli White and Ostrea malachitensis Stanton.

\section{Zone of Prionocyclus macombi}

Prionocyclus macombi Meek (1876b, p. 132, pl. 2, fig. 3a-d) was described from beds now assigned to the basal part of the Juana Lopez Member of the Carlile Shale of northeastern New Mexico. This slender, nearly smooth species is abundant in New Mexico and southwestern Colorado, but it is uncommon farther north. Inoceramus dimidius White is found with it at many localities. Two subzones can be recognized in New Mexico. The older subzone has Coilopoceras colleti Hyatt (1903, p. 91, pl. 10, figs. 5-21; pl. 11, fig. 1) as a guide fossil, and the younger has C. inflatum Cobban and Hook $(1980$, p. 19, pl. 1, figs. 9-11; pl. 11, fig. 2; pls. 12-17; pl. 18, figs. $1-3,11-13$; pls. 20,21 ; text figs. 14,15 ).

The holotype of Coilopoceras colleti came from the lower part of a sandstone unit now named the Fite Ranch Member of the Tres Hermanos Formation (Hook and others, 1983). In the type area of the Fite Ranch Member near the former coal- mining town of Carthage in south-central New Mexico, C. colleti is found with $P$. macombi, Lopha bellaplicata novamexicana Kauffman, and species of Pinna, Aphrodina?, Legumen, Homomya, Psilomya, Pholadomya, and a few gastropods.

The holotype of Coilopoceras inflatum Cobban and Hook (1980, p. 19, pl. 11, fig. 2; text fig. 15A) came from a limestone concretion in the basal part of the D-Cross Tongue of the Mancos Shale in west-central New Mexico. Fossils associated with this ammonite in New Mexico include $P$. macombi, Inoceramus dimidius White, and Lopha lugubris (Conrad). The ammonite Hourcquia cf. $H$. mirabilis Collignon has been found at a few localities.

\section{Zone of Prionocyclus wyomingensis}

The types of Prionocyclus wyomingensis Meek (1876a, p. 452; White, 1883 , p. 35 , pl. 15, fig. la-e) came from rocks now assigned to the Wall Creek Sandstone Member of the Frontier Formation in southeastern Wyoming. This evolute, well-ribbed, keeled ammonite has inner and outer ventrolateral tubercles.

Prionocyclus wyomingensis occurs at many localities in a belt that extends from the Black Hills southwestward through the southeast part of Wyoming and then spreads out over most of Colorado, the eastern half of Utah, and the northern half of New Mexico. The species has been found in the Turner Sandy Member of the Carlile Shale along the flanks of the Black Hills; in the Wall Creek Member of the Frontier Formation in Wyoming; in the Frontier Sandstone Member of the Mancos Shale in northeastern Utah and northwestern Colorado; in the Juana Lopez Member of the Mancos Shale in southwestern Colorado, central eastern Utah, and northwestern New Mexico; in the Juana Lopez Member of the Carlile Shale in southeastern Colorado and northeastern New Mexico; and in the lower part of the D-Cross Tongue of the Mancos Shale in westcentral New Mexico.

The zone of Prionocyclus wyomingensis can be divided into two subzones on the basis of the genus Scaphites. Scaphites warreni Meek and Hayden (1860, p. 177; Meek, 1876a, p. 420, pl. 6, fig. 5) characterizes the older subzone, which contains Inoceramus dimidius White, Lopha lugubris (Conrad), and Baculites undulatus d'Or- 
bigny. A late form of Prionocyclus macombi occurs here as well as an occasional specimen of Coilopoceras inflatum. The younger subzone is marked by Scaphites ferronensis Cobban (1951b, p. 23, pl. 4, figs. 16-29), which contains Inoceramus dimidius and Lopha lugubris at the top of their range.

\section{Zone of Scaphites whitfieldi}

The most densely ribbed scaphite in the Western Interior is Scaphites whitfieldi Cobban (1951b, p. 24 , pl. 4, figs. 30-40; pl. 5, figs. 1-4). It is abundant in the Western Interior from south-central Montana to southern New Mexico. Important fossils found with $S$. whitfieldi are Inoceramus perplexus Whitfield (1880, p. 392, pl. 8, fig. 3; pl. 10, figs. 4, 5) and Prionocyclus novimexicanus (Marcou). The latter differs from $P$. wyomingensis by loss of the outer ventrolatral tubercles on the adults (Hook and Cobban, 1979).

Scaphites whitfieldi is found in calcareous and ferruginous concretions in the Carlile Member of the Cody Shale in south-central Montana and in similar concretions in the Turner Sandy Member of the Carlile Shale along the flanks of the Black Hills. In north-central, south-central, and southeastern Wyoming, the species occurs in similar concretions as well as in sandstone beds in the Frontier Formation. The species has been collected from gray limestone concretions in the Mancos Shale a little above the Frontier Sandstone Member in northwestern Colorado and northeastern Utah. Specimens are locally abundant in the uppermost part of the Juana Lopez Member of the Mancos Shale in east-central Utah, western Colorado, and northern New Mexico. The species also is present in calcareous and sandy concretions in the D-Cross Tongue of the Mancos Shale in west-central and southern New Mexico. In southeastern Colorado, a few specimens have been collected from an unnamed calcareous shale member at the top of the Carlile Shale.

\section{Zone of Prionocyclus quadratus}

Prionocyclus quadratus Cobban (1953a, p. 354, pl. 48, figs. 1-8), the last of a lineage of prionocyclids, was described from calcareous concretions in the Sage Breaks Member of the Carlile Shale on the northern and eastern flanks of the Black Hills in southeastern Montana and western South Dakota. Other fossils in these concretions are scarce but include Inoceramus cuvieriformis Pergament, Mytiloides incertus (Jimbo), Baculites yokoyamai Tokunaga and Shimizu, Scaphites corvensis Cobban, and Placenticeras sp. The same fauna has been found in calcareous concretions in the lower part of the Cody Shale farther west in north-central Wyoming.

Sidwell (1932, p. 318, pl. 49, figs. 10-12) described as a new species Prionocyclus reesidei from the Frontier Formation of Wyoming. He based his species on the holotype, a small specimen from the Medicine Bow area in southeastern Wyoming, and on a much larger paratype from near Rawlins in south-central Wyoming. In the Medicine Bow area, the only unit in the Frontier that contains prionocyclids is the Wall Creek Sandstone Member, which has very small impressions of juvenile $P$. macombi in the basal part and larger specimens of $P$. wyomingensis in sandy concretions in the upper part. The types of $P$. wyomingensis Meek (1876a, p. 452) came from these concretions as did Sidwell's holotype of $P$. reesidei. It is possible that Sidwell's holotype is the inner whorls of a coarse-ribbed $P . w y$ omingensis. Sidwell's much larger paratype, however, came from a younger sandstone unit in the Frontier Formation. Bivalves in this sandy unit include Mytiloides incertus, which suggests an age equivalent to that of $P$. quadratus. Sidwell's paratype could be interpreted as a compressed form of $P$. quadratus.

Crushed fragments of prionocyclids in the unnamed calcareous shale member at the top of the Carlile Shale in Colorado may represent $P$. quadratus. Mytiloides incertus is found with them. Typical $P$. quadratus are scarce in New Mexico. Prionocyclids in Cretaceous sandstone on the southwestern flank of the San Andres Mountains in southern New Mexico may represent a compressed geographic subspecies. Associated fossils include abundant $\boldsymbol{M}$. incertus. 


\section{Dansk sammendrag}

En række stratigrafisk vigtige ammonitfaunaer af mellem cenomanien - $\emptyset v r e$ turonien alder fra det indre af USA er beskrevet. I den sydlige del af området indeholder faunaerne en del Tethys-elementer og kan derfor zoneres finere end de nordlige og også korreleres bedre regionalt. En zonering, der vil kunne danne grundlag for regional korrelering, er opstillet. Grænserne mellem mellem og øvre cenomanien, cenomanien og turonien, nedre og mellem turonien samt mellem og øvre turonien er defineret. Af sarlig vigtighed er opstillingen af en rakke ammonitzoner omkring cenomanien-turonien grænsen, zoner, der kun er ufuldstændig kendt fra Europa. Grænsen mellem cenomanien og turonien defineres mellem Neocardioceras juddii zonen og Pseudaspidoceras flexuosum zonen.

\section{References}

Adkins, W. S. 1928: Handbook of Texas Cretaceous fossils. Texas Univ. Bull.2838, $385 \mathrm{pp}$.

Barrois, C. \& de Guerne, J. 1878: Description de quelques espèces nouvelles de la Craie de l'est du Bassin de Paris. Soc. géol. Nord Ann.5, 42-64.

Bergquist, H. R. 1944: Cretaceous of the Mesabi iron range, Minnesota. J. Paleont. 18 (1), 1-30.

Choffat, P. 1898: Les ammonées du Bellasien, des Couches à Neolobites Vibrayeanus, du Turonien et du Sénonien, 2d ser., of Recueil d'études paléontologiques sur la faune crétacique du Portugal, v. 1, Espèces nouvelles ou peu connues. Sect. Travaux géol. Portugal, 41-86.

Chudeau, R. 1909: Ammonites du Damergou (Sahara Meridional): Bull. Soc. géol. Fr. (4) 9, 67-71.

Cobban, W. A. 1951a: Colorado shale of central and northwestern Montana and equivalent rocks of Black Hills. Bull. Am. Ass. Petrol. Geol. 35 (10), 2170-2198.

Cobban, W. A. 1951b: Scaphitoid cephalopods of the Colorado group. Prof. Pap. U.S. Geol. Surv. 239, 42 pp.

Cobban, W. A. 1953a: A new species of Prionocyclus from Upper Cretaceous Carlile shale. J. Paleont. 27 (3), 353355.

Cobban, W. A. 1953b: Cenomanian ammonite fauna from the Mosby sandstone of central Montana. Prof. Pap. U.S. Geol. Surv. 243-D, 45-55.

Cobban, W. A. 1958: Late Cretaceous fossil zones of the Powder River Basin, Wyoming and Montana. Wyoming Geol. Ass. Guidebook 13th Ann. Field Conf., Powder River Basin, 114-119.

Cobban, W. A. 1961: The ammonite family Binneyitidae Reeside in the western interior of the United States. J. Paleont. 35 (4), 737-758.

Cobban, W. A. 1971: New and little-known ammonites from the Upper Cretaceous (Cenomanian and Turonian) of the western interior of the United States. Prof. Pap. U.S. Geol. Survey 699, 24 pp.

Cobban, W. A. 1977: Characteristic marine molluscan fossils from the Dakota Sandstone and intertongued Mancos Shale, west-central New Mexico. Prof. Pap. U.S. Geol. Surv. $1009,30 \mathrm{pp}$.

Cobban, W. A. 1983: Molluscan fossil record from the northeastern part of the Upper Cretaceous seaway, Western Interior, in Cobban, W. A., \& Merewether, E. A., Statigraphy and paleontology of mid-Cretaceous rocks in Minnesota and contiguous areas. Prof. Pap. U.S. Geol. Surv.1253, pp. 1-25.
Cobban, W. A. \& Hook, S. C. 1979: Collignoniceras woollgari woollgari (Mantell) ammonite fauna from Upper Cretaceous of Western Interior, United States. New Mexico Bur. Mines \& Min. Resources Mem. 37, 51 pp.

Cobban, W. A. \& Hook, S. C. 1980: The Upper Cretaceous (Turonian) ammonite family Coilopoceratidae Hyatt in the Western Interior of the United States. Prof. Pap. U.S. Geol. Surv. 1192, 28 pp.

Cobban, W. A. \& Hook, S. C. 1981: New turrilitid ammonite from the mid-Cretaceous (Cenomanian) of southwestern New Mexico: New Mexico Bur. Mines \& Min. Resources Circ. 180, 22-29.

Cobban, W. A. \& Hook, S. C. 1983: Mid-Cretaceous (Turonian) ammonite fauna from Fence Lake area of westcentral New Mexico. New Mexico Bur. Mines \& Min. Resources Mem. 41, $50 \mathrm{pp}$.

Cobban, W. A. \& Reeside, J. B., Jr. 1952: Correlation of the Cretaceous formations of the Western Interior of the United States. Bull. Geol. Soc. Am. 63 (10), 1011-1043.

Cobban, W. A. \& Scott, G. R. 1972: Stratigraphy and ammonite fauna of the Graneros Shale and Greenhorn Limestone near Pueblo, Colorado. Prof. Pap. U.S. Geol. Surv. $645,108 \mathrm{pp}$.

Crick, R. E. 1978: Morphological variations in the ammonite Scaphites of the Blue Hill Member, Carlile Shale, Upper Cretaceous, Kansas. Univ. Kans. Paleont. Contr. 88, 28 pp.

Feldmann, R. M. \& Maxey, M. 1980: Raninella carlilensis, a new raninid crab from the Carlile Shale (Turonian) of Kansas. J. Paleont. 54 (4), 858-861.

Haas, O. 1949: Acanthoceratid Ammonoidea from near Greybull, Wyoming. Bull. Am. Mus. Nat. Hist. 93 (1), 39 pp.

Haas, O. 1963: Paracanthoceras wyomingense (Reagan) from the Western Interior of the United States and from Alberta (Ammonoidea). Am. Mus. Novitates 2151, $19 \mathrm{pp}$.

Haas, O. 1964: Plesiacanthoceras, new name for Paracanthoceras Haas, 1963, non Furon, 1935. J. Paleont. 38 (3), 610 .

Hall, J. \& Meek, F. B. 1856: Descriptions of new species of fossils from the Cretaccous formations of Nebraska, with observations upon Baculites ovatus and $B$. compressus, and the progressive development of the septa in Baculites, Ammonites, and Scaphites. Mem. Am. Acad. Arts \& Sci. (n. ser.) $5,379-411$

Hattin, D. E. 1962: Stratigraphy of the Carlile Shale (Upper Cretaceous) in Kansas. Kansas Geol. Surv. Bull. 156, 155 pp.

Hattin, D. E. 1968: Plesiacanthoceras wyomingense (Reagan) from Graneros Shale and Greenhorn Limestone (Upper Cretaceous) of central Kansas. J. Paleont. 42 (4), 10841090.

Hook, S. C. \& Cobban, W. A. 1977: Pycnodonte newberryi (Stanton)-common guide fossil in Upper Cretaceous of New Mexico, in Kottlowski, F. E. \& others, New Mexico Bur. Mines \& Min. Resources Ann. Report 1976-1977, 48-54.

Hook, S. C. \& Cobban, W. A. 1979: Prionocyclus novimexicanus (Marcou)-common Upper Cretaceous guide fossil in New Mexico, in Kottlowski, F. E. \& others.New Mexico Bur. Mines \& Min. Resources Ann. Report 1977-1978, 34-42.

Hook, S. C. \& Cobban, W. A. 1981: Late Greenhorn (midCretaceous) discontinuity surfaces, southwest New Mexico. New Mexico Bur. Mines \& Min. Resources Circ. 180, 5-21. 
Hook, S. C., Cobban, W. A. \& Landis, E. R. 1980: Extension of the intertongued Dakota Sandstone-Mancos Shale terminology into the southern Zuni Basin. New Mexico Geology 2 (3), 42-44, 46.

Hook, S. C., Molenaar, C. M. \& Cobban, W. A. 1983: Stratigraphy and revision of nomenclature of upper Cenomanian to Turonian (Upper Cretaceous) rocks of west-central New Mexico. New Mexico Bur. Mines \& Min. Resources Circ. 185, 1-28.

Hyatt, A., Edited by T. W. Stanton 1903: Pseudoceratites of the Cretaceous. U.S. Geol. Surv. Monogr. 44, 351 pp.

Kennedy, W. J. 1970: A correlation of the uppermost Albian and the Cenomanian of south-west England. Proc. Geol. Ass. 81 (4), 613-677.

Kennedy, W. J., Wright, C. W. \& Hancock, J. M. 1980: Collignoniceratid ammonites from the Mid-Turonian of England and northern France. Palaeontology 23 (3), 557-603.

Knechtel, M. M. \& Patterson, S. H. 1956: Bentonite deposits in marine Cretaceous formations, Hardin district, Montana and Wyoming. Bull. U.S. Geol. Surv. 1023, $116 \mathrm{pp}$.

Mantell, G. 1822: The fossils of the South Downs, or illustrations of the geology of Sussex. London, Lupton Relfe, 327 pp.

Meek, F. B. 1876a: A report on the invertebrate Cretaceous and Tertiary fossils of the upper Missouri country. U.S. Geol. Surv. Territories (Hayden) Report 9, $629 \mathrm{pp}$.

Meek, F. B. 1876b: Descriptions of the Cretaceous fossils collected on the San Juan exploring expedition under Capt. J. N. Macomb, U.S. Engineers, in Macomb, J. N., Report of the exploring expedition from Sante Fe... in 1859.U.S. Engineering Depart., 119-133.

Meek, F. B. \& Hayden, F. V. 1859: Descriptions of new organic remains collected in Nebraska Territory... together with some remarks on the geology of the Black Hills and portions of the surrounding country. Acad. Nat. Sci. Philadelphia, Proc. 1858, p. 41-59.

Meek, F. B. \& Hayden, F. V. 1860: Descriptions of new organic remains from the Tertiary, Cretaceous, and Jurassic rocks of Nebraska. Acad. Nat. Sci. Philadelphia, Proc. 1860, 175-185.

Meek, F. B. \& Hayden, F. V. 1861: Descriptions of new Lower Silurian (Primordial), Jurassic, Cretaceous, and Tertiary fossils collected in Nebraska Territory...; with some remarks on the rocks from which they were obtained. Acad. Nat. Sci. Philadelphia, Proc. 1861, 415-447.

Meek, F. B. \& Hayden, F. V. 1862: Descriptions of new Cretaceous fossils from Nebraska Territory, collected by the expedition... under the command of Lieut. John Mullan... Acad. Nat. Sci. Philadelphia Proc. 1862, 21-28.

Merewether, E. A. 1983: Lower Upper Cretaceous strata in Minnesota and adjacent areas - time-stratigraphic correlations and structural attitudes, in Cobban, W. A., and Merewether, E. A., Stratigraphy and paleontology of midCretaceous rocks in Minnesota and contiguous areas: Prof. Pap. U.S. Geol. Surv. 1253, 27-52.

Merewether, E. A. \& Cobban, W. A. 1981: Mid-Cretaceous formations in eastern South Dakota and adjoining areasstratigraphic, paleontologic, and structural interpretations, in Cretaceous stratigraphy and sedimentation in northwest Iowa, northeast Nebraska, and southeast South Dakota. Iowa Geol. Surv. Guidebook Ser. 4, 43-56.
Merewether, E. A., Cobban, W. A. \& Cavanaugh, E. T. 1979: Frontier Formation and equivalent rocks in eastern Wyoming. The Mountain Geologist, 16 (3), 67-101.

Moreman, W. L. 1927: Fossil zones of the Eagle Ford of north Texas. J. Paleont. 1 (1), 89-101.

Moreman, W. L. 1942: Paleontology of the Eagle Ford group of north and central Texas. J. Paleont. 16, (2), 192-220.

Morrow, A. L. 1935, Cephalopods from the Upper Cretaceous of Kansas. J. Paleont. 9 (6), 463-473.

Pillmore, C. L. \& Eicher, D. L. 1976: Lower part of the marine Cretaceous at Gold Creek, Vermejo Park, New Mexico. New Mexico Geol. Soc. Guidebook 27th Field Conf., Vermejo Park, 171-176.

Powell, J. D. 1963: Cenomanian-Turonian (Cretaceous) ammonites from Trans-Pecos Texas and northeastern Chihuahua, Mexico. J. Paleont. 37 (2), 309-322.

Reagan, A. B. 1924: Cretacic Mollusca of Pacific slope. PanAmerican Geologist, 41, 179-190.

Reeside, J. B., Jr. 1944: Maps showing thickness and general character of the Cretaceous deposits in the western interior of the United States. U.S. Geol. Surv. Oil \& Gas Inv. Map 10.

Shumard, B. F. 1860: Descriptions of new Cretaceous fossils from Texas. Trans. Acad. Sci. St. Louis 1, 590-610.

Sidwell, R. 1932: New species from the Colorado group, Cretaceous, in south-central Wyoming. J. Paleont. 6 (4), 312318.

Stanton, T. W. 1893: The Colorado formation and its invertebrate fauna: Bull. U.S. Geol. Surv. 106, 288 pp.

Stanton, T. W. 1909: Succession and distribution of later Mesozoic invertebrate faunas in North America. J. Geology 17 (5), 410-423.

Stephenson. L. W. \& Reeside, J. B., Jr. 1938: Comparison of Upper Cretaceous deposits of Gulf region and western interior region. Bull. Am. Ass. Petrol. Geol. 22 (12), 16291638 .

White, C. A. 1878: Report on the geology of a portion of northwestern Colorado. U.S. Geol. \& Geog. Surv. Territories (Hayden) Ann. Report 10, $60 \mathrm{pp}$.

White, C. A. 1883: Contributions to invertebrate paleontology, No. 2; Cretaceous fossils of the Western States and Territories. U.S. Geol. \& Geog. Surv. Territories (Hayden) Ann. Report 12, Pt. 1, 5-39.

Whitfield, R. P. 1880: Paleontology of the Black Hills of Dakota, in Newton, Henry, \& Jenney, W. P., Report on the geology and resources of the Black Hills of Dakota. U.S. Geog. \& Geol. Surv. Rocky Mountain Region (Powell), $325-468$.

Wright, C. W. \& Kennedy, W. J. 1981: The Ammonoidea of the Plenus Marls and the Middle Chalk. Palaeontographical Soc. (Monogr.), 148 pp.

Young, K. 1957: Cretaceous ammonites from eastern Apache County, Arizona. J. Paleont. 31, (6) 1167-1174. 